\title{
AN INVESTIGATION OF INDIVIDUAL FUNCTIONALITY FOOTBALL REFEREES QUALIFICATIONS
}

Berezka S.M., Chopilko T.G.

Kiev National Economic University

National University of Physical Education and Sport of Ukraine

\begin{abstract}
Annotation. Purpose: determine the level of individual functionality referees qualifications. Objective of the study was to determine the physiological parameters characterizing the functionality of football referees qualifications. Material: mainly experiment involved 29 highly qualified referees aged 21-45 years. In the main experiment participated 29 referees and 40 assistant referees $(n=69)$ Ukrainian Premier League. Results: found that the means and methods that use Ukrainian football referee high qualification in the special physical training for a competition, are not effective enough. Consequence of poorly planned training process is to increase the number of wrong decisions of the referees during the match associated with poor motor activity. Conclusions: data obtained in the course of educational research confirmed our theory about the necessity of individualization process special physical training qualifications of referees, which would entail increasing the functional and motor abilities of the referees, and as a consequence of better and successful completion of the work.
\end{abstract}

Keywords: referee, individualization, preparation, planning, error.

\section{Introduction}

Basing on recommendations of FIFA and UEFA we can say that physical training of football referees is of priority, especially when it concerns highly qualified referees.

Recent time testing of referees' special physical fitness takes place 4 times a season that helps for referees to maintain good physical form during all season and for managers of "Referees' committee" receive information about their current condition.

That is requirements to highly qualified referees' physical fitness are constantly increasing; psychological indicators and theoretical level go after them $[1,6]$.

The problem of referees' physical fitness was regarded in works by A.B. Abdula, A.D. Budgorskiy, K.L. Vikhrov, Yu.F. Kuznetsov, P.M. Kulalayev, A.N. Spirin, Yt.A. Turbin [1-7], et al. The works of the mentioned authors were oriented on training of referees of initial qualification or touched aspects of their psychological and theoretical levels. Special physical training of referees and its individualization was regarded by the authors only fragmentary or did not studied at all. In spite of the fact that all authors noted that it was the most important component in work of football referee.. That is why research of individualization of highly qualified football referees' special physical training is urgent as on to day $[1-3,5,7]$.

This research is a part of scientific-research work, which was fulfilled in compliance with combined plan of SRW in sphere of physical culture and sports for 2011-2015 by topic 2.3 "Scientific-methodic principles of perfection of football sportsmen's training system considering specificities of competition functioning" (state registration number $0111 \mathrm{U} 001722$ ).

Purpose, tasks of the work, method and material of the research

The purpose of the work is to theoretically and experimentally ground need in individualization of special physical training of highly qualified football referees.

For solution of our task we used the following methods and organization of the research:

1. Pedagogic studying, analysis and generalization of scientific methodic literature, pedagogic observation, photo and video recording of different game situations, questioning;

2. Statistical analysis of the results.

Results of the research

During all sport season highly qualified football referees take part in conducting of official competitions of country and cup championships as well as international matches (referees of FIFA category) [4].

Recent years, quantity of games, conducted by highly qualified referees within frames of all-Ukrainian competitions, has been remaining relatively unchanged [1].

In season of 2012-2013 in 239 matches of Ukrainian Supreme league there were engaged 26 referees; the most wanted referee of Supreme league judged 15 matches and mean indicators of matches per one referee was 9.2. Having compared indicators of Ukrainian highly qualified referees with indicators of advanced European referees of 2012-2013 season we can surely say that domestic referees receive in season much less assignments for matches than referees from other countries. The highest load in season is endured by referees of England Supreme league; mean quantity of matches, conducted by one English referee in one season is 20 (see fig. 1) [8].

Such indicators are connected, first of all, with insufficient physical fitness of our referees that is a result of wrong approach to training process; football referee of high qualification shall be ready to long and tensed competition [3].

If badly trained player can be replaced by other player in one match then referee cannot be replaced. High level of physical fitness shall be maintained by referee during all season, which takes 9 months [1]. 


\section{Country}

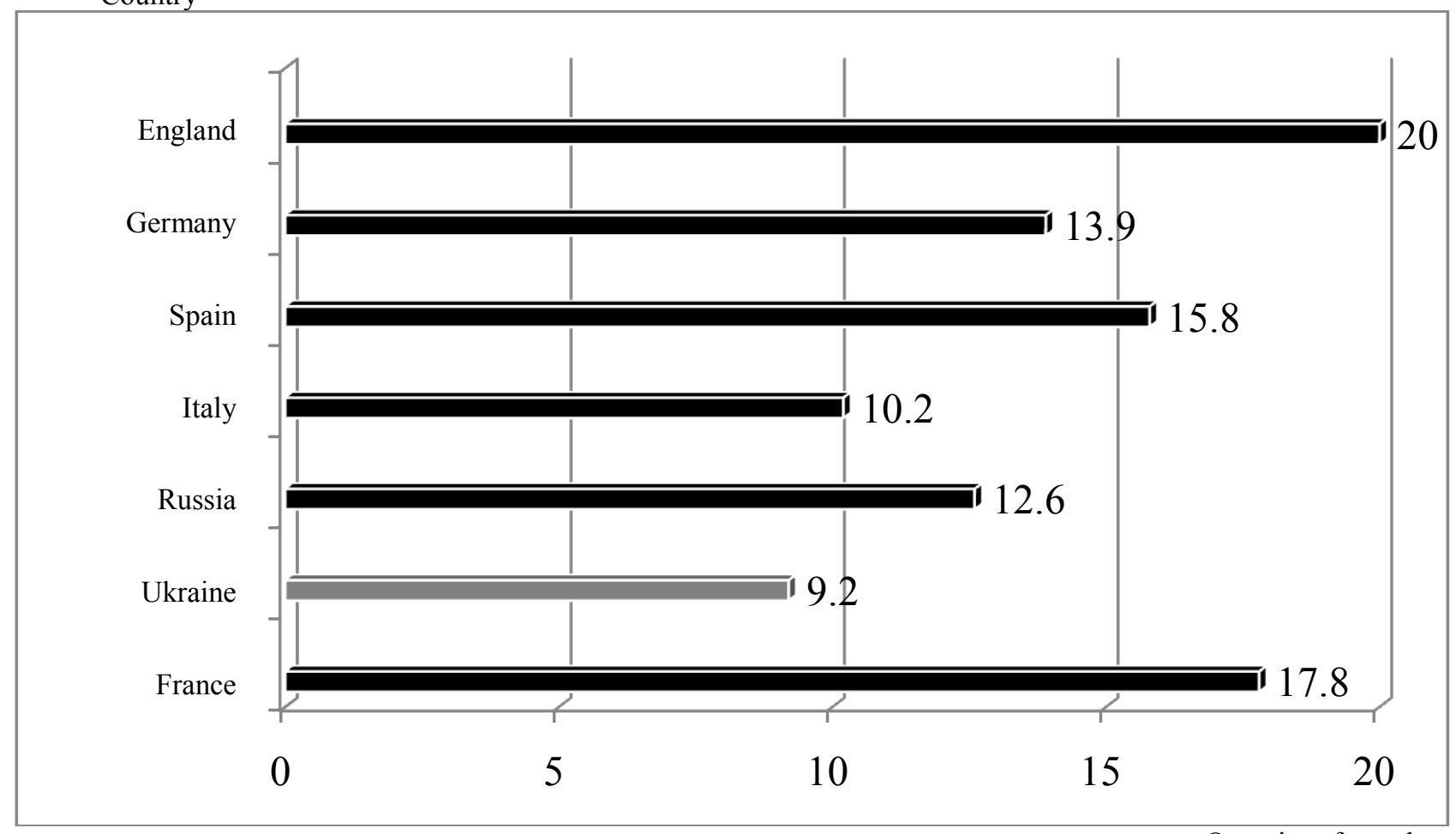

Quantity of matches

Fig.1. Comparative statistics of matches' quantity during season, conducted by highly qualified referees of Ukraine and advanced football championships of Europe (season 2012-2013.).

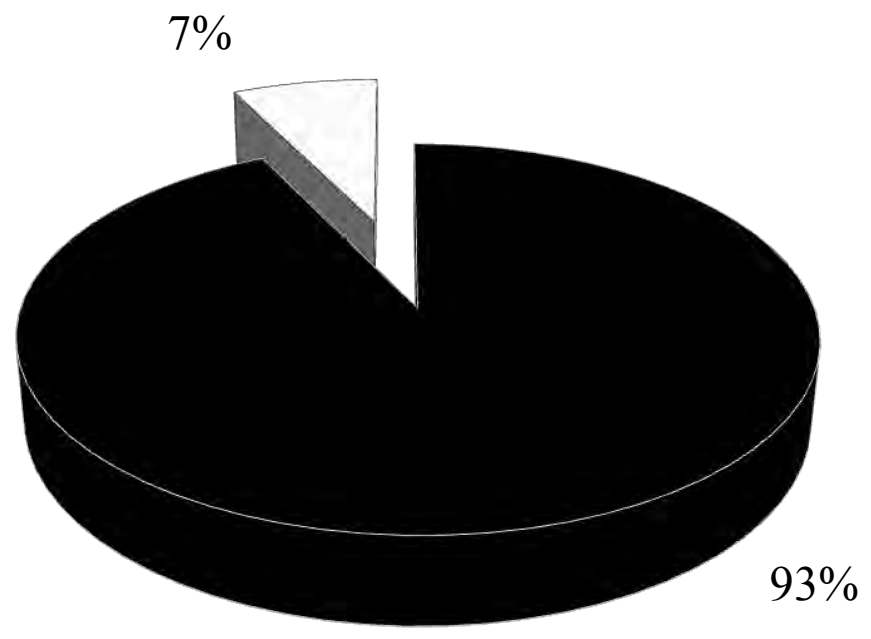

- POSITIVE

NEGATIVE

Fig.2. Attitude of referees and referees' assistants of Ukrainian Supreme League to individualization of special physical training

Analysis of results of our pedagogic questioning of 29 referees and 40 referees' assistants ( $n=69)$ (Supreme league of Ukraine) showed that $86.6 \%$ of referees feel, as a rule, significant physical tiredness after every match. Tensed matches noticeably influence on nervous muscular system and a number of functional indicators of referees [9].

Our questionnaire consisted of 16 questions, which were oriented on determination of factors, which, in opinion of referees, influence on effectiveness of special physical fitness and high level of functional state. 
Besides, the questionnaire included question, determining referees' and referees assistants' attitude to individualization of special physical fitness on the base of individual peculiarities of development of their motion skills and functional potentials (see fig.2).

$93 \%$ of respondents answered this question positively. Only $7 \%$ have negative attitude to individualization ogf special physical training.

Achieving and maintaining of high level of special physical fitness in process of practical refereeing during all season can surely facilitate both higher quality of refereeing and referee's ability to cope with constantly increasing competition load $[1,3,5,6,8]$.

The fulfilled by us researches in frames of video reviewing of refereeing, conducted by highly qualified referees permit to see not only quantitative picture of every 15-minutes' period of match but also to determine distance at which referees take decisions about violation of rules and determine interconnection of special physical fitness and quantity of referees' correct and wrong actions (see figs. 3, 4, 5).

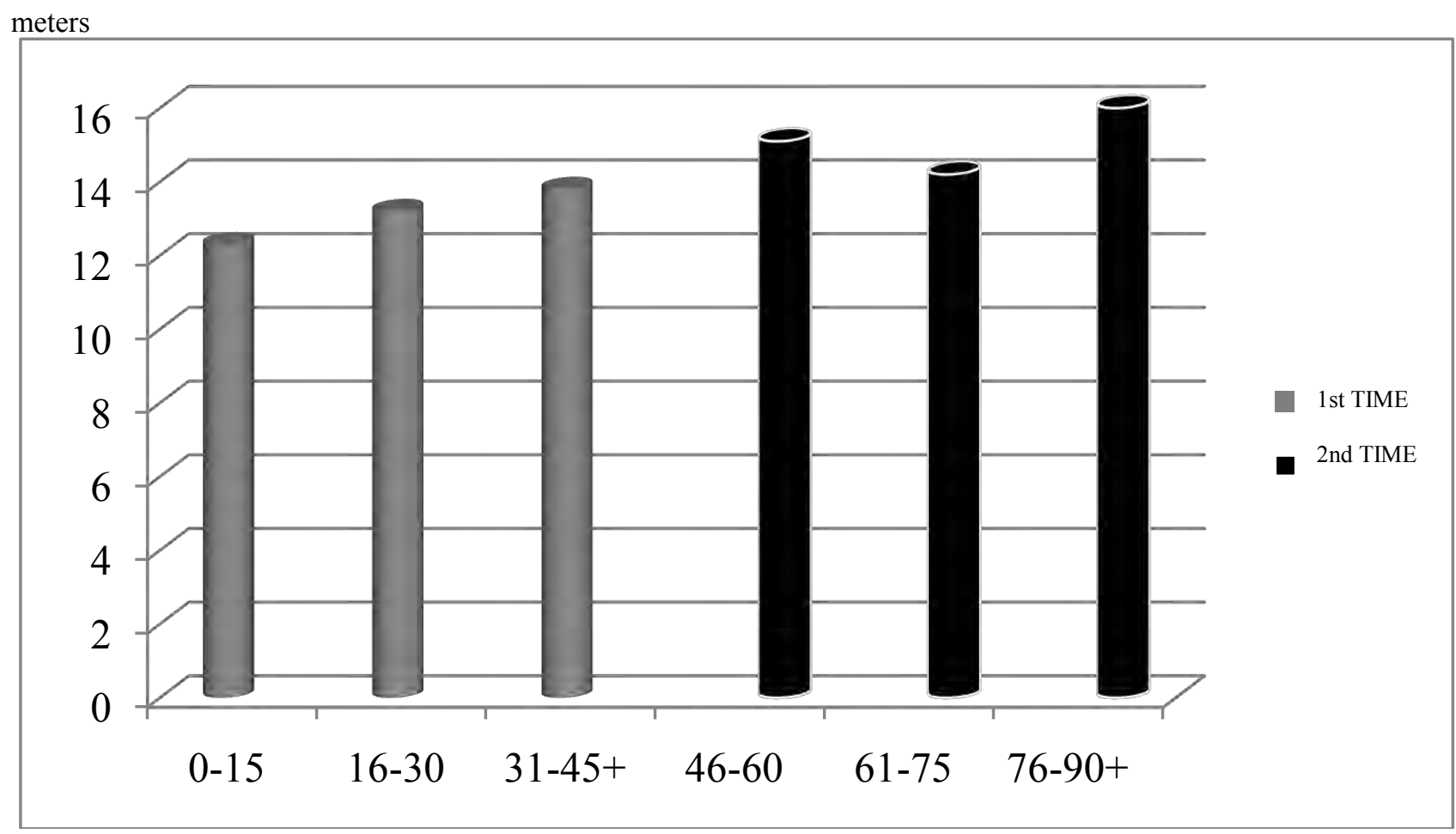

minutes

Fig.3 Mean distance from referee to place of rule's violation (differentiated by 15 minutes' periods) (in meters)

Having analyzed the data of supplied above figures we can see noticeable trend to increasing of mistakes with increasing of distance from referee's position to match's episode at moment of taking of decision.

Basing on all received in the course of our pedagogic researches data we can make definite conclusions that all means and methods, which are used by highly qualified referees in process of special physical training for com,petitions are not sufficiently effective that results in refereeing with insufficient quality. 
meters

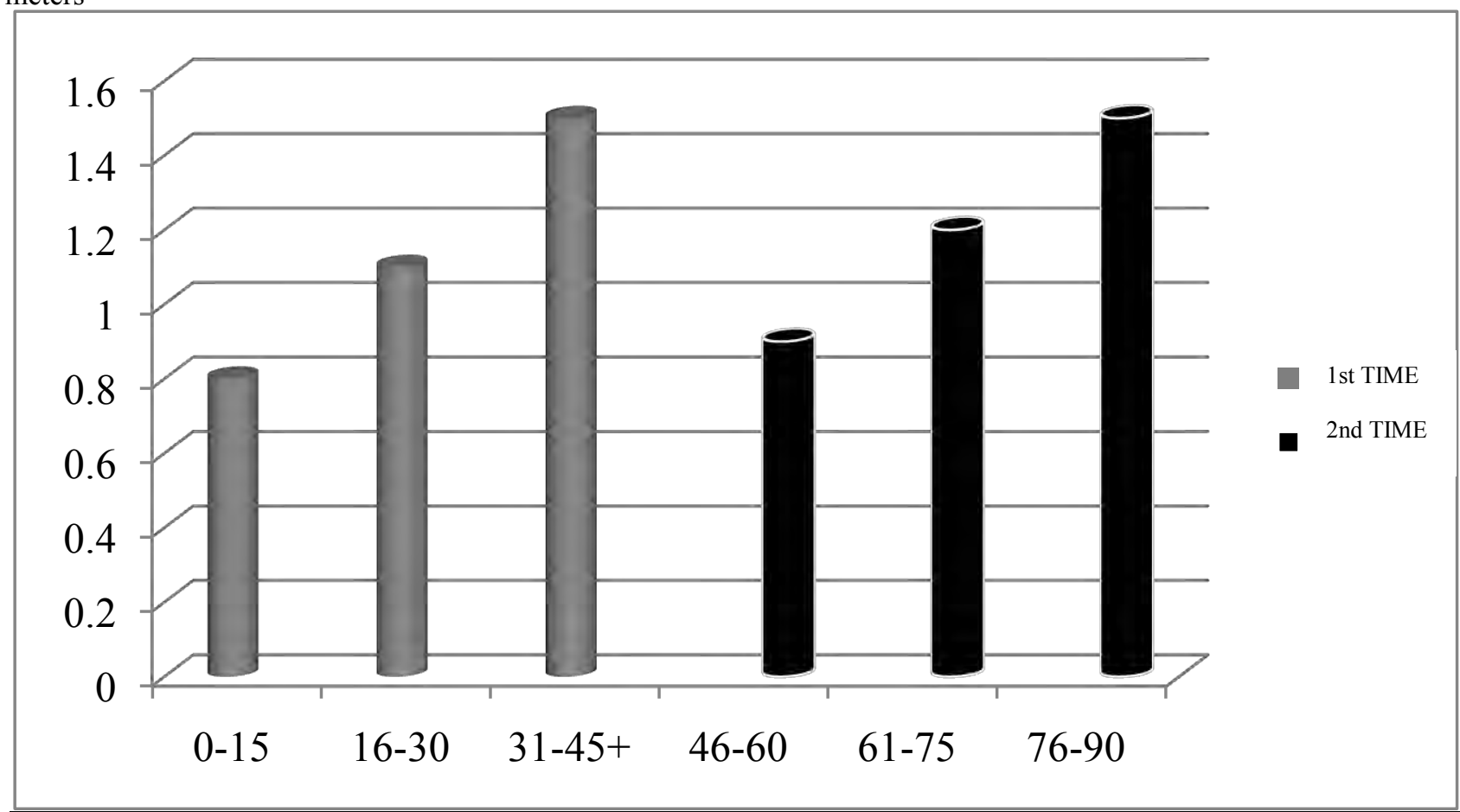

minutes

Fig.4. Mean quantity of referees' wrong decisions on interpretation of rules and on stoppages of match (differentiated by 15 minutes' periods)

meters

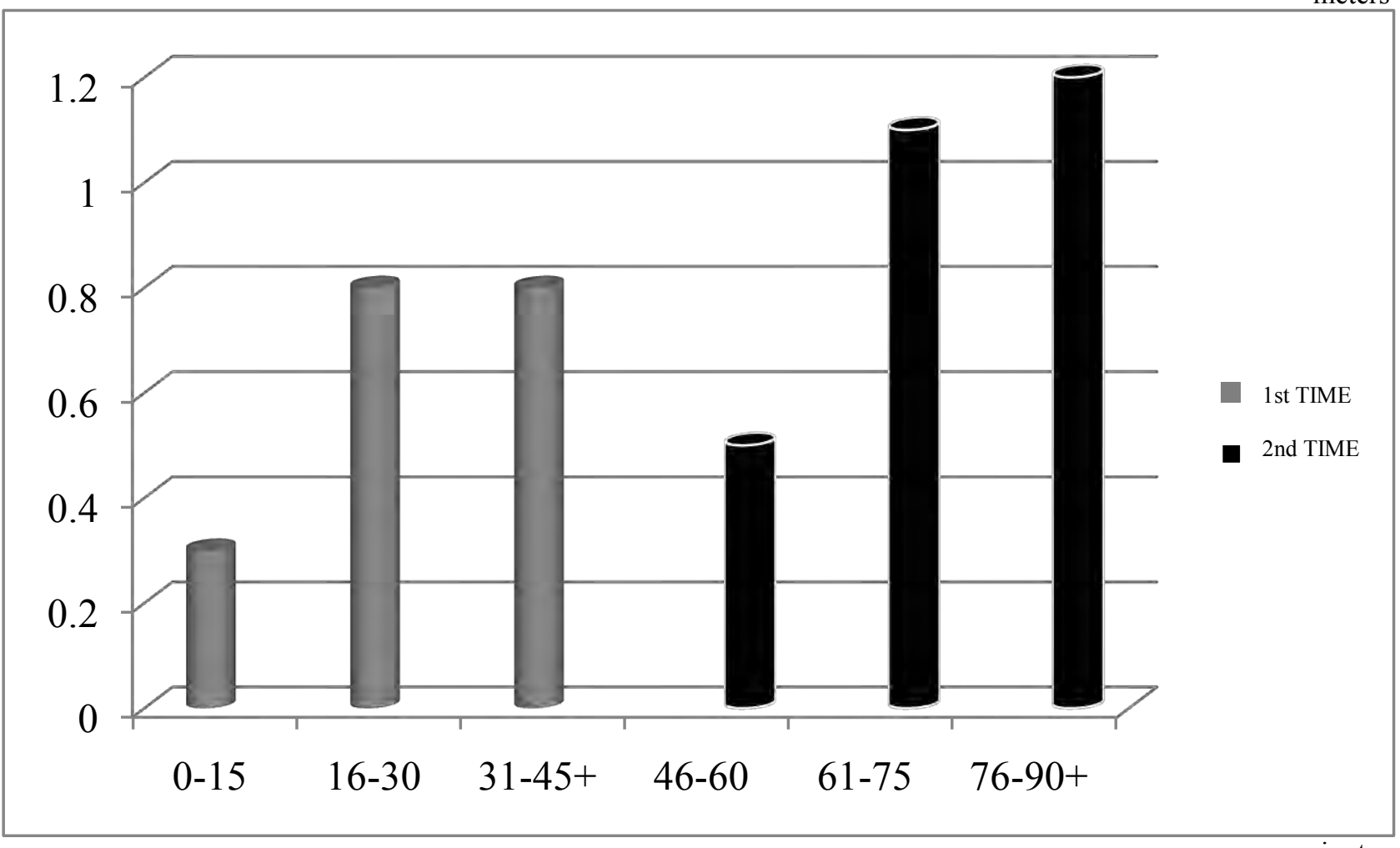

Fig.5. Mean quantity of violations, not noticed by referee (differentiated by 15 minutes' periods)

\section{Conclusions:}

Modern football requires from referee's special physical fitness high standards that are witnessed by results of our researches; see below brief conclusions.

With the help of pedagogic questioning, in which 29 referees and 40 referees' assistants of Ukrainian Supreme league took part, we determined that highly qualified referees apply in training process quite different methodic and 
programs, oriented on perfection of general and special physical fitness. Personal experience and self feeling of referees were the basis of planning of their trainings loads.

$93 \%$ of respondents $(n=69)$ noted that individualization of special physical training of highly qualified referees on the base of development of their motion abilities and functional potentials is required.

All received in pedagogic researches data proved our theory about demand in individualization of special physical training of highly qualified referees that will result in increasing of referees' functional potentials and, consequently, fulfillment of their work with higher quality.

The next stage of our research will be preparation of individual programs on special physical training of highly qualified referees.

\section{References:}

1. Abdula A.B. Udoskonalennia fizichnoyi pidgotovki futbol'nikh arbitriv riznoyi kvalifikaciyi [Improving physical fitness football referees with different qualifications], Cand. Diss., Kharkiv, 2011, 20 p.

2. Budogosskij A.D. Organizacionno-pedagogicheskie aspekty postroeniia processa professional'noj podgotovki futbol'nykh arbitrov nachal'noj kategorii [Organizational and pedagogical aspects of the process of constructing training football referees primary category], Cand. Diss., Moscow, 2008, 26 p.

3. Vikhrov K.L. Kompan'en futbol'nogo arbitra [Assistant soccer referee], Kiev, Combi LTD, 2006, 150 p.

4. Zemcova I.I. Sportivna fiziologiia [Sports physiology], Kiev, Olympic Literature, 2008, 208 p.

5. Iordanskaia F.A., Iudinceva M.S. Monitoring zdorov'ia $i$ funkcional'naia podgotovlennost' vysokokvalificirovannykh sportsmenov v processe uchebno-trenirovochnoj raboty i sorevnovatel'noj deiatel'nosti [Monitoring the health and functional preparedness of elite athletes during training work and competitive activities], Moscow, Soviet sport, 2006, 184 p.

6. Karpman V.L., Belocerkovskij Z.B., Gudkov I.F. Testirovanie v sportivnoj medicine [Testing in sports medicine], Moscow, Physical Culture and Sport, 1988, 207 p.

7. Kuznecov Iu.F. Teoriia i praktika fizicheskoj kul'tury [Theory and practice of physical culture], 2000, vol.7, pp. 34-38.

8. Kulalaev P.M. Nachal'naia podgotovka futbol'nykh arbitrov [Initial training of football referees], Volga, 2006, 165 p.

9. Spirin A.N., Budogosskij A.D. Sudejstvo: vzgliad na problemu [Refereeing: A look at the problem], Moscow, 2003, $274 \mathrm{p}$.

10. Matveev L.P. Osnovy obshchej teorii sporta i sistemy podgotovki sportsmenov [The general theory of sport and the system of training athletes], Kiev, Olympic Literature, 1999, 317 p.

11. Turbin E.A. Vybor pozicii i napravlenie peremeshcheniia arbitrami v khode igry [Selecting the position and direction of movement of the arbitrators in the course of the game], 2004, $17 \mathrm{p}$.

12. Castagna C. Training the Italian Football Referees. Coaching and Sports Science Journal. 2008, vol.3, pp. 6-7.

13. Di Salvo V, Gregson W, Atkinson G, Tordoff P, Drust B. Analysis of High Intensity Activity in Premier League Soccer. International Journal of Sports Medicine. 2009, vol.30, pp. 205-212.

14. Mallo J, Navarro E, Garcia-Aranda JM, Gilis B, Helsen W. Analysis of the Kinematical Demands Imposed on Top-Class Assistant Referees During Competitive Soccer Matches. Journal of Strength and Conditioning Research. 2008, vol.22, pp. 235-242.

15. Weston M, Castagna C, Impellizzeri FM, Rampinini E, Abt G. Analysis of Physical Match Performance in English Premier League Soccer Referees with Particular Reference to First Half and Player Work Rates. Journal of Science and Medicine in Sport. 2007, vol.10, pp. 390-397.

\section{Information about the authors:}

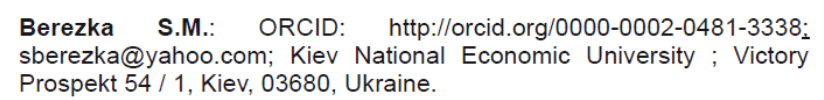

Chopilko T. G.: ORCID: http://orcid.org/0000-0002-9851-3511; chopilkotaras@bigmir.net; National University of Physical Education and Sport of Ukraine; Fizkultury str. 1, Kiev, 03680, Ukraine.

Cite this article as: Berezka S.M., Chopilko T.G. An investigation of individual functionality football referees qualifications. Physical education of students, 2014, vol.6, pp. 8-12. doi: $10.15561 / 20755279.2014 .0602$

The electronic version of this article is the complete one and can be found online at: http://www.sportpedu.org.ua/html/arhive-e.html

This is an Open Access article distributed under the terms of the Creative Commons Attribution License, which permits unrestricted use, distribution, and reproduction in any medium, provided the original work is properly cited (http:// creativecommons.org/licenses/by/3.0/deed.en). 